\title{
UTILIZATION OF SOLAR ENERGY IN GREENHOUSE HEATING DURING WINTER SEASON IN EGYPT
}

\author{
Sahar S. Nasser' ${ }^{1}$, Adel H. Bahnasawy ${ }^{2}$, Taha H. Ashour ${ }^{2}$ and El-Sayed G. Khater ${ }^{3 \& *}$ \\ ${ }^{1}$ MSc Stud., Ag. Eng. Dept., Fac. of Ag., Benha U., Egypt. \\ ${ }^{2}$ Prof., Ag. Eng. Dept., Fac. of Ag., Benha U., Egypt. \\ ${ }^{3}$ Assoc. Prof., Ag. Eng. Dept., Fac. of Ag., Benha U., Egypt. \\ * E-mail: alsayed.khater@fagr.bu.edu.eg
}

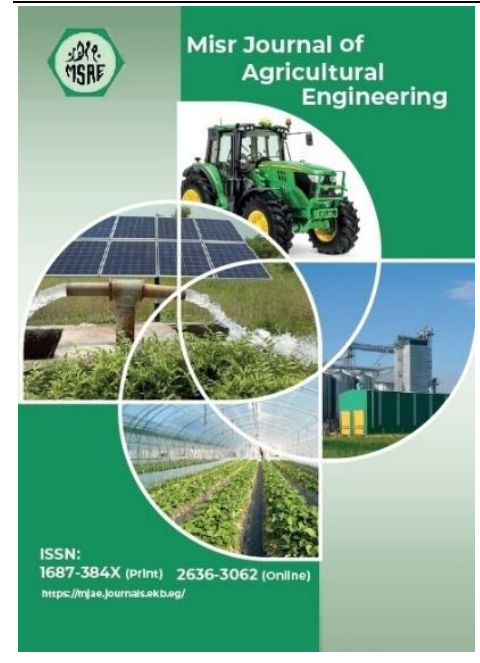

(C) Misr J. Ag. Eng. (MJAE)

Keywords:

Cucumber, solar energy, air temperature, fruit weight, yield

\begin{abstract}
The main aim of this study is to investigate the utilization of solar energy as a renewable energy source and compared to the traditional energy in greenhouses heating during winter season. To achieve that study, the effect of two different heating systems (Traditional heating (G1) and solar heating (G2)) on the cucumber growth parameters during growth period and cucumber fruit characteristics and total yield were investigated. Temperature and relative humidity during the growth season were recorded. The obtained results indicated that the indoor air temperatures ranged from 18.78 to 25.29 and 18.00 to $25.15{ }^{\circ} \mathrm{C}$ for $G 1$ and $G 2$, respectively, whereas the outdoor air temperature ranged from 11.00 to $21.66{ }^{\circ} \mathrm{C}$. The temperatures were added by using electrical (G1) and solar energy (G2) for greenhouse heating ranged from 1.5 to 9.3 and 0.85 to $7.78^{\circ} \mathrm{C}$, respectively, during experimental period. The indoor relative humidity ranged from 63.33 to 88.67 and 70.93 to $93.94 \%$ for G1 and G2, respectively, whereas the outdoor air relative humidity ranged from 45.93 to $92.73 \%$. The plant length, stem diameter and total leaf area values for cucumber grown in Gl were higher than those of the plant growth in G2. The fruit length was 24.79 and $19.44 \mathrm{~cm}$ for $G 1$ and $G 2$, respectively. The fruit diameters were 3.36 and $3.19 \mathrm{~cm}$ for $G 1$ and $G 2$, respectively. The results also indicate that the fruit weight and number of fruits per plant were 115.07 and $108.73 \mathrm{~g}$ and 19 and 17 for $G 1$ and G2, respectively. The total yield values of cucumber were 182.09 and $152.92 \mathrm{~kg}$ for G1 and G2, respectively, during growth period.
\end{abstract}

\section{INTRODUCTION}

7 he use of renewable energy sources is becoming increasingly necessary, as clean source of energy to avoid pollution global warming resulting from using traditional energy. Solar energy is the most common form of renewable energy, widely used in the third world but until recently, less so in the Western world. Latterly much attention has been focused on identifying suitable biomass species, which can provide high-energy outputs, to replace conventional fossil fuel energy sources. 
Greenhouse is one of the most profitable sectors since it has a very high output which is 10 to 20 times higher than the outdoor horticulture (Vadiee and Mortin, 2012). Nowadays, the impact of the fuel price crisis coupled with the awareness of global problem has brought changes in the structure of energy usage all over the world. Greater importance has now been given to research, development, and operation of clean (renewable) energy, for a greater energy security. Renewable energy is accepted as a key source for the future, not only for Egypt but also for the whole-world. Renewable energy technologies produce marketable energy by converting natural phenomena into useful forms of energy. These technologies use the sun's energy and its direct and indirect effects on the earth (solar radiation, wind, falling water, and various plants residual, i.e. biomass. Egypt has a considerably high level of renewable energy sources particularly solar energy that can be contributed a large part of the total heat energy required in the country. The benefits arising from the installation and operation of renewable energy system can be distinguished into three categories; energy saving, generation of job opportunities, and the decrease of environmental pollution (Khater et al., 2020).

Optimum temperature for plant growth in the generative phase is usually lower than in the vegetative phase due to the low leaf area ratio and high maintenance respiration in the generative stage (Challa et al., 1995). Also, optimum temperature for fruit production may be different from that for overall plant growth (plant dry mass). Most commercial cucumber crops under glass in northern Europe are grown at sub-optimum temperatures for overall plant growth, once fully developed (Slack and Hand, 1983 and Grimstad and Frimanslund, 1993). Higher temperature in the early stage of growth promotes leaf expansion and thus light interception, as well as flowering, fruit development and early yield (Slack and Hand, 1983 and Challa et al., 1995). Furthermore, higher temperature might enhance early fruit growth at the expense of vegetative growth (de Koning 1988). While early yield was high at higher night temperature (NT), there was no difference in final yield (Slack and Calvert, 1978).

Air temperature also affects fruit quality. Cucumber fruit development is closely related to daily average air temperature. When the growth of cucumber fruit is not constrained by assimilate supply, the strong increase in fruit growth rate with increasing temperature over-compensates for the reduction of the fruit growth period, resulting in an increase in marketable fruit size (Marcelis and Hofman-Eijer, 1993). High temperature $\left(30^{\circ} \mathrm{C}\right)$ may reduce the keeping quality of cucumber (Challa et al., 1995). Therefore, for a multiple-harvest greenhouse fruit crop like cucumber, the optimum temperature management for efficient cucumber production should ensure an appropriate balance between vegetative and reproductive growth, and between the growth of existing fruit and the emergence of new leaves and flowers that will sustain continuous fruit production (Challa et al., 1995). Also, when seeking savings in greenhouse heating, air temperature should not be lowered to a level that reduces fruit yield and quality (Slack and Hand, 1983).

Growth of high quality vegetables in greenhouses in Northern climates relates to the creation of optimum growth conditions including optimum temperatures. Due to severe environmental problems caused by fossil fuels there is an increasing interest to use renewable endogenous energy resources for heating them particularly if they are cost effective. Among renewable energies the most important for providing the necessary heat in the greenhouses are solar energy, geothermal energy and biomass, (Vourdoubas, 2004 and Sethi and Sharma, 2008). 
Lazaar et al. (2015) presented a research to compared two types of greenhouse heating system. Two heating sources were used in order to increase the nocturnal air temperature under greenhouse: an Electrical Heating System (EHS) and a Solar Heating System (SHS). The efficiency of the solar collector was determined and the effectiveness of the evacuated tube solar collector with a water storage tank was also examined. The average value of energy efficiencies of the evacuated tube solar water heater was about $46 \%$. The EHS allowed an increase of inside air temperature of $4{ }^{\circ} \mathrm{C}$ while using the SHS permitted temperature rise of 2 ${ }^{\circ} \mathrm{C}$. An economic analysis showed that the use of a system of 3 evacuated tube solar collectors for greenhouse heating was rentable since the payback period of the solar system was 3 years. In another study, a low cost Seasonal Solar Soil Heat Storage (SSSHS) system used for greenhouse heating was invented and investigated (Zhzng et al., 2015).

Due to the gradually raising of traditional energy prices and its effects on the environmental pollution besides the increasing of production costs, therefore, the main aim of this work is to use a clean, renewable and low cost source of energy to heat the agricultural greenhouse during the winter season.

\section{MATERIALS AND METHODS}

The experiment was carried out at Fish Farms and Protected Houses Center, Faculty of Agriculture Moshtohor, Benha University, Egypt (latitude $30^{\circ} 21^{`} \mathrm{~N}$ and $31^{\circ} 13^{`} \mathrm{E}$ ). During the period of December, 2018 to March, 2019.

\subsection{Materials:}

\subsubsection{System description:}

Figure (1) illustrates the experimental setup. It shows the system which consists of greenhouses, solar energy system, electrical heating system and irrigation system.
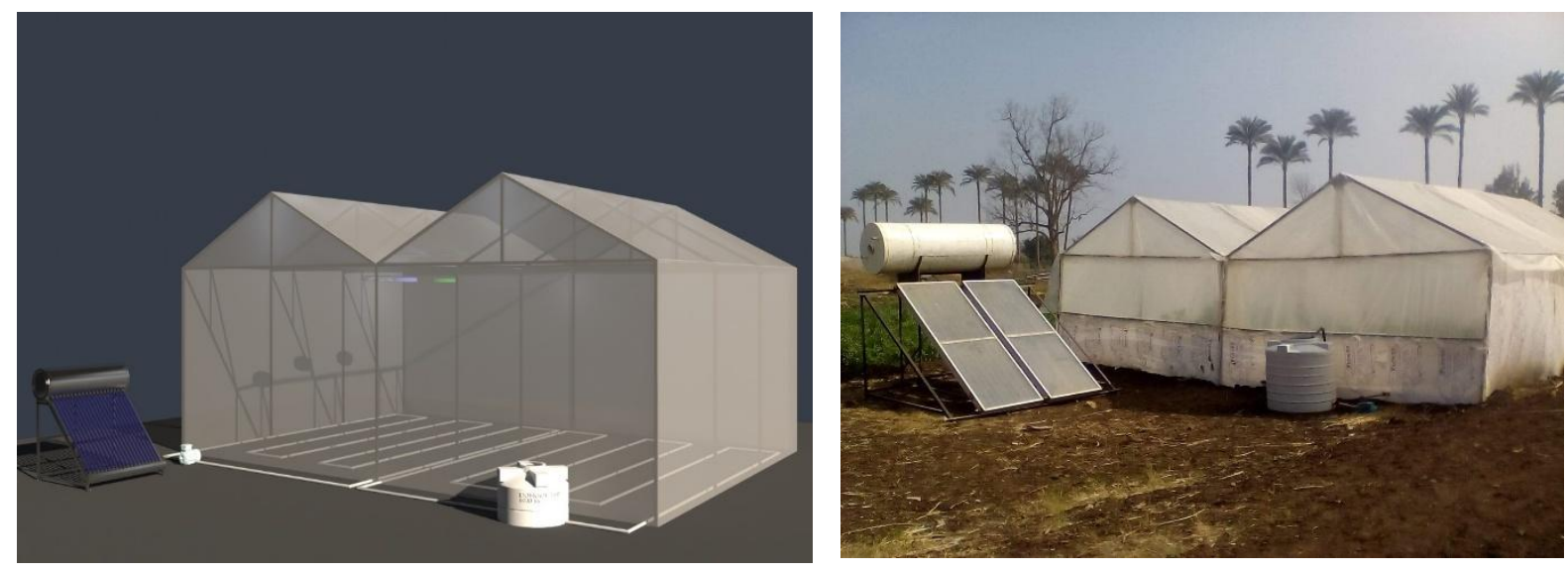

Figure (1): The experimental setup.

\subsubsection{Greenhouses construction:}

Two identical gable-even-span from greenhouse were used during this research work. Each one having a geometrical characteristics of: total length of $6 \mathrm{~m}$, total width of $4 \mathrm{~m}$, vertical wall height of $3.0 \mathrm{~m}$, and floor surface area of $24 \mathrm{~m}^{2}$. The greenhouse structural frame was formed of $4 \mathrm{x} 4 \mathrm{~cm}$ hot dipped galvanized box with excellent anti-corrosion. The walls of greenhouse were covered by using $4 \mathrm{~mm}$ thick polycarbonate panels and the roof of greenhouse was covered by using 150 micron Polyethylene sheets. The structure frame consisted of many parts (posts, beams, rafters and trusses) which easily assembled on the spot with joining parts and 
bolts and nuts, without any welding points to prevent damage the zinc coating on the material, which guarantee the optimal performance of anti-corrosion. The space between each two successive spans on the longitudinal direction is $2.0 \mathrm{~m}$. Figure (2) shows the schematic diagram of gable-even-span greenhouse. The two greenhouses were orientated in East-West direction, where the southern longitudinal direction faced into the sun's rays and the northern longitudinal direction faced into the cold sky.

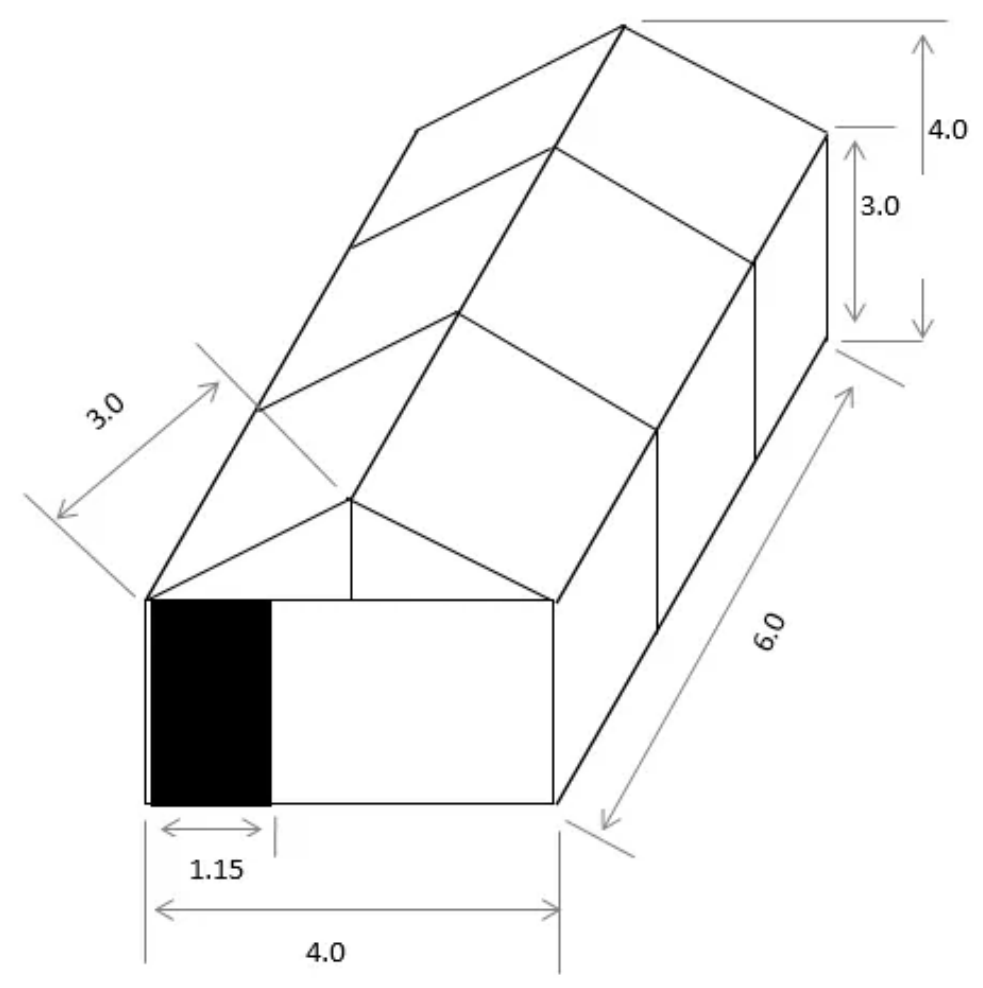

Figure (2): The schematic diagram of gable-even-span greenhouse.

\subsubsection{Solar energy system:}

The solar water heater consists of 2 individual solar collector panels each having a gross dimension of $2.0 \mathrm{~m}$ long, $1.0 \mathrm{~m}$ wide and $0.1 \mathrm{~m}$ thick with net surface area of $2.0 \mathrm{~m}^{2}$, constructed from copper with a selectively absorbing surface coating and covered with $5 \mathrm{~mm}$ thermal clear glass. The operating fluid (pure water) flowed through parallel waterways built into each panel. The solar panel will not operate at its peak potential unless it is tilted and orientated from the horizontal plane in such a way that it will minimize the angle of incidence and maximize the transmittance of glass cover and absorptance of the absorber plate. Consequently, it will receive and absorb the maximum amount of solar energy flux incident. Therefore, each twelve solar panels are mounted on a movable frame outside the greenhouse so that to track the sun's rays from sunrise to sunset. The operating fluid has pumped to pass through the solar collector panels. After passing through the solar collector panels, it was stored in a $0.5 \mathrm{~m}^{3}$ insulated storage tank. This tank is cylindrical in shape and made from polyethylene which fulfilled by foam liquid as an insulating material in order to minimize the heat energy loss from the storage tank. The storage tank connected to the solar collector panels by two junctions of insulated hot galvanized pipes $25.4 \mathrm{~mm}$ (1.0 inch) diameter. Figure (3) shows the solar water heater. The hot 
water was circulated by a pump (Model First QB60 - Flow Rate $30 \mathrm{~L} \mathrm{~min}^{-1}$ - Head $25 \mathrm{~m}$ Power $0.5 \mathrm{hp}$, China) from the heating tank to the heat exchanger.
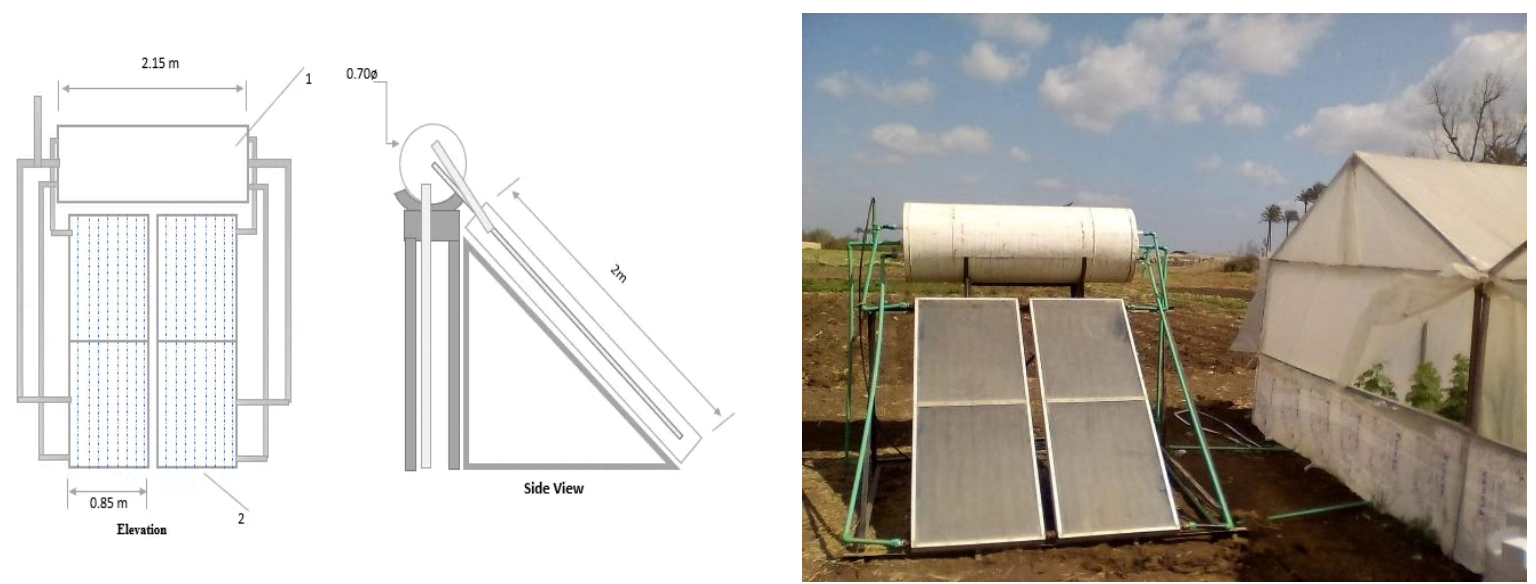

Figure (3): The solar water heater.

\subsubsection{Convential heating system:}

The electrical heating system consists of heating tank $0.50 \mathrm{~m}^{3}$ capacity that used for heating water. Dimensions of heating tank are $0.90 \mathrm{~m}$ diameter and $0.75 \mathrm{~m}$ high. It is made of polyethylene and covered by glass rock sheet. Electric heater $(2 \mathrm{~kW})$ was used for water heating as shown in figure (4). The hot water was circulated by a pump (Model First QB60 - Flow Rate $30 \mathrm{~L} \mathrm{~min}^{-1}$ - Head $25 \mathrm{~m}$ - Power $0.5 \mathrm{hp}$, China) from the heating tank to the heat exchanger automatically.

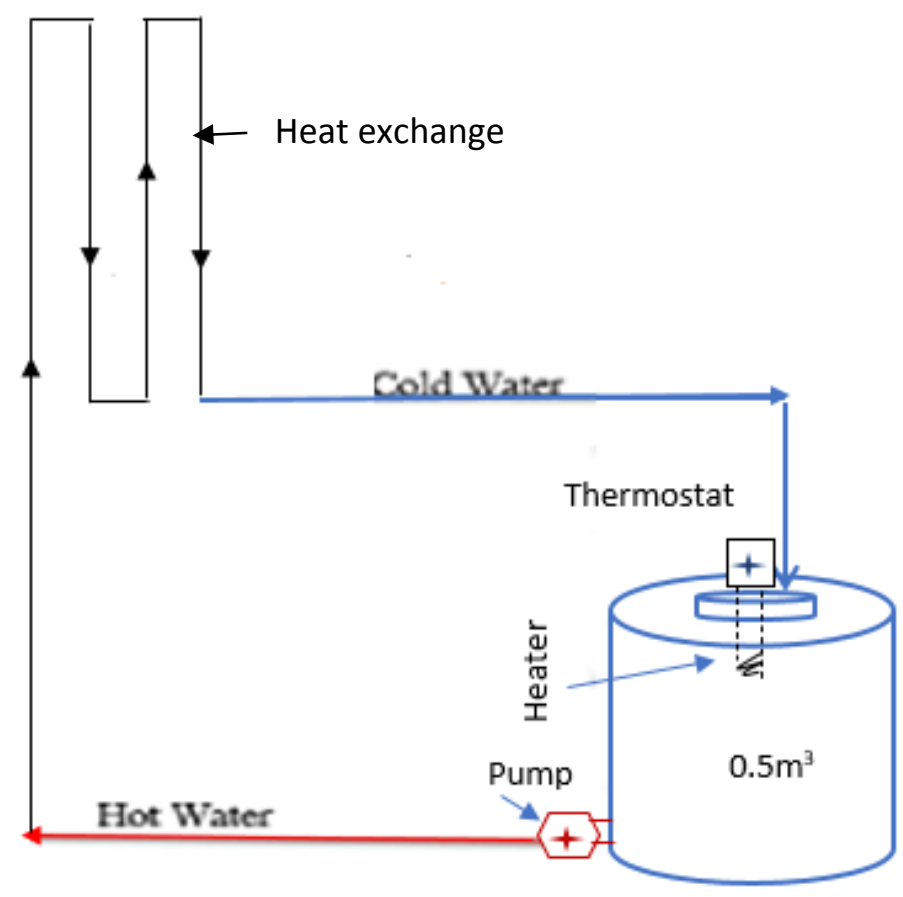

Figure (4): The electrical heating system.

\subsubsection{Heat energy distribution system (heat exchanger):}

The two greenhouses were equipped with a complete heat exchanger tubes installed inside the greenhouse with parallel flow system for heating indoor air. The system was mainly consisted 
of three parallel rows of hot galvanized pipes (38.1 mm diameter). Parallel water galvanized pipes were placed at a horizontal equidistance of $1.5 \mathrm{~m}$ between two successive rows. The heat exchangers (heat distribution system) are installed inside the two greenhouses on a block to be above the floor surface by $30 \mathrm{~cm}$.

\subsubsection{Irrigation system:}

Drip irrigation system was installed inside the two greenhouses to provide the cucumber with the necessary water during the growth period. It consists of water pump, fertigation unit, main pipe line ( $\varphi 50 \mathrm{~mm}$ diameter) and sub-main pipe line ( $\varphi 16 \mathrm{~mm}$ diameter).

\subsubsection{Cucumber crop:}

Three-week-old cucumber seedlings (Hesham varity) were planted in the greenhouse on $1^{\text {st }}$ December, 2018, at $30 \mathrm{~cm}$ spacings between plants within the row. Water consumptive use $\left(\mathrm{mm}\right.$ day $\left.^{-1}\right)$ was calculated and applied according to the climate data using the PenmanMonteith method described by (FAO, 1991), and according to local weather station data, which located in Moshtohor. After soil preparation, $0.5 \mathrm{~m}^{3}$ of compost was added. Fertilizer requirements of cucumber were applied as recommended by Agronomy Research Institute (ARC) Ministry of Agriculture and Land Reclamation.

\subsection{Methods:}

\subsubsection{Measurements}

Temperature and relative humidity inside and outside greenhouses were recorded by using a HOBO Data Logger (Model HOBO U12 Temp/RH/Light - Range -20 to $70^{\circ} \mathrm{C}$ and 5 to $95 \%$ $\mathrm{RH}, \mathrm{USA}$ ) every hour. Three cucumber plants representing each treatment to determine shoot length, stem diameter, number of leaves, leaf area, shoot and root dry weight. Shoot length was measured by using a digital caliper (Model TESA 1p65- Range 0-150 $\mathrm{mm} \pm 0.01 \mathrm{~mm}$, Swiss). A planimeter (Model Placom KP -90 N- Range 0-10 m2 $\pm 0.2 \%$, Japan) was used to measure the leaf area of the cucumber plants. Fresh shoots of cucumber plants were weighed and placed in drying oven with circulating air at $65{ }^{\circ} \mathrm{C}$ for $48 \mathrm{~h}$ then weighed or at constant weight for dry weight. Fruit yield, fruit weight and number of fruits per plant were also determined at the end of the experiment.

\section{RESULTS AND DISCUSSION}

\section{Indoor air temperature of the greenhouses:}

Figure (5) shows the indoor air temperatures for the two greenhouses (G1 and G2) had compared with the outdoor air temperatures. The indoor air temperatures ranged from 18.78 to 25.29 and 18.00 to $25.15^{\circ} \mathrm{C}$ for G1 and G2, respectively, whereas the outdoor air temperature ranged from 11.00 to $21.66^{\circ} \mathrm{C}$. The indoor air temperatures in $\mathrm{G} 1$ were higher than those of $\mathrm{G} 2$. The highest value of indoor air temperature $\left(25.29^{\circ} \mathrm{C}\right)$ was found in $\mathrm{G} 1$, while the lowest value of indoor air temperature $\left(18.00{ }^{\circ} \mathrm{C}\right)$ was found from $\mathrm{G} 2$. In combination with the minimum air temperature requirements of the most commonly cultivated cucumber crop is $14.52{ }^{\circ} \mathrm{C}$ as recommended by Nelson (2006). The temperatures were added by using electrical and solar energy for greenhouse heating ranged from 1.5 to 9.3 and 0.85 to $7.78{ }^{\circ} \mathrm{C}$, respectively, during experimental period.

Figure (6) shows the hourly average indoor air temperatures for the two greenhouses (G1 and G2) had compared with the hourly average outdoor air temperatures. The hourly average indoor 
air temperatures were ranged from 18.78 to 30.25 and 10.30 to $26.83{ }^{\circ} \mathrm{C}$ for $\mathrm{G} 1$ and $\mathrm{G} 2$, respectively, whereas the outdoor temperature ranged from 9.43 to $21.79{ }^{\circ} \mathrm{C}$. The highest values of hourly average indoor air temperature were 30.25 and $26.83{ }^{\circ} \mathrm{C}$ for $\mathrm{G} 1$ and $\mathrm{G} 2$, respectively, were found at $1.00 \mathrm{PM}$, while the lowest value of hourly average indoor temperatures was 18.78 and $10.30{ }^{\circ} \mathrm{C}$ for $\mathrm{G} 1$ and $\mathrm{G} 2$, respectively, were found at $6.00 \mathrm{AM}$.

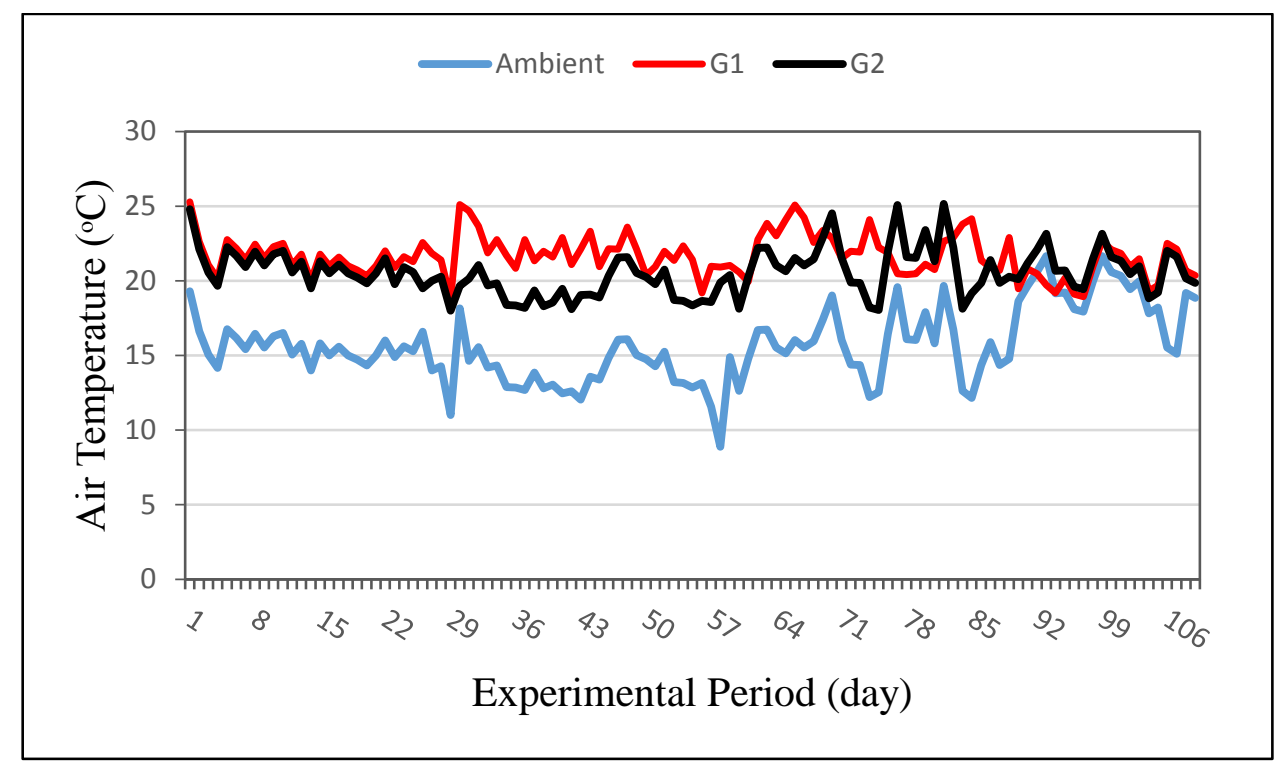

Figure (5): The daily average air temperatures diurnal changes in temperatures of the air inside and outside the greenhouses.

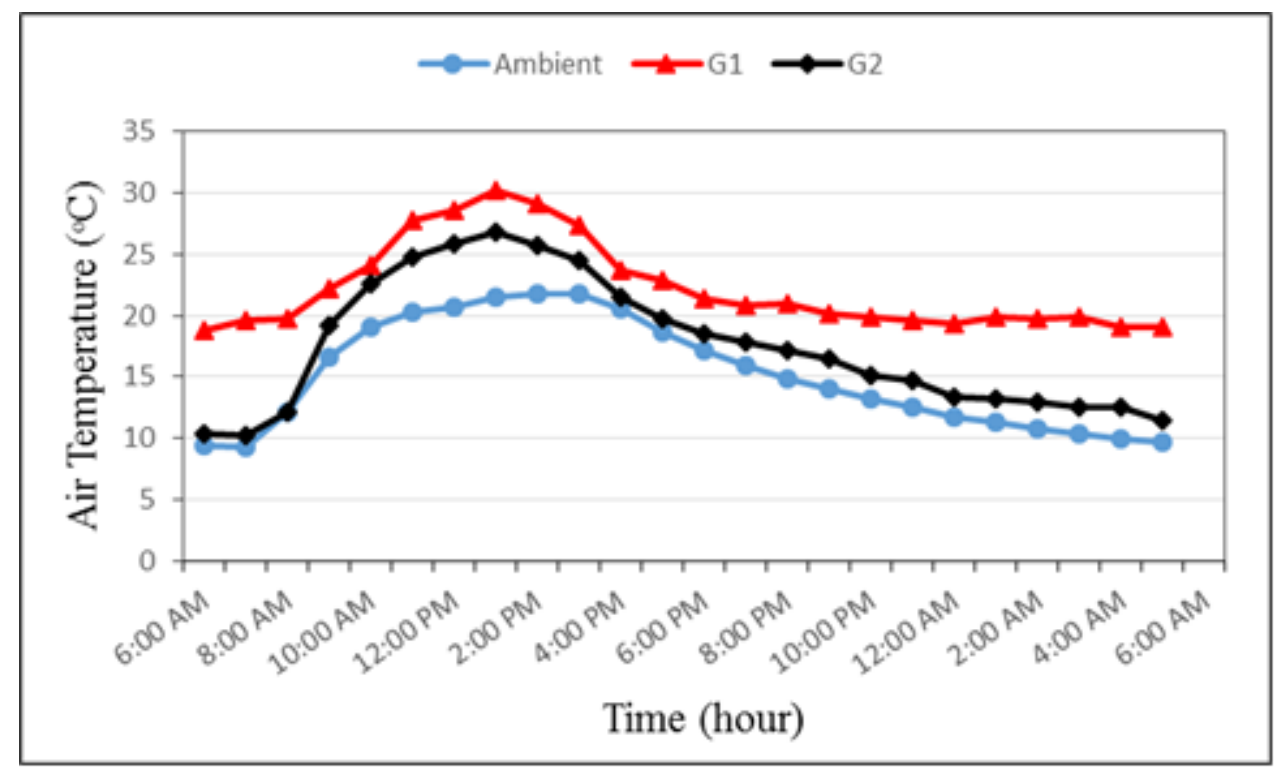

Figure (6): The hourly average air temperatures inside and outside the greenhouses.

\section{Indoor air relative humidity of the greenhouses:}

Figure (7) shows the indoor air relative humidity for the two greenhouses: (G1 and G2) had compared with the outdoor relative humidity. The indoor relative humidity ranged from 63.33 to 88.67 and 70.93 to $93.94 \%$ for G1 and G2, respectively, whereas the outdoor air relative humidity ranged from 45.93 to $92.73 \%$. The indoor air relative humidity in G2 was higher than those of G1. The highest value of indoor air relative humidity (93.94\%) was found from G2, 
while the lowest value of indoor air relative humidity $(63.33 \%)$ was found from G1. Most protected cropping grows best within a fairly restricted range, typically 60 to $80 \%$ air relative humidity for many varieties (Öztürk and Başçetinçelik, 2003b). High air relative humidity is the response of pathogenic organisms. Most pathogenic spores cannot germinate at air relative humidity below $85 \%$. Lower air relative humidity increases the evaporative demand on the plant to the extent that moisture stress can occur, even when there is an ample supply of water to the roots. Normal plant growth inside the greenhouse generally occurs at air relative humidity ranged from 50 to $80 \%$ (Hanan, 1998).

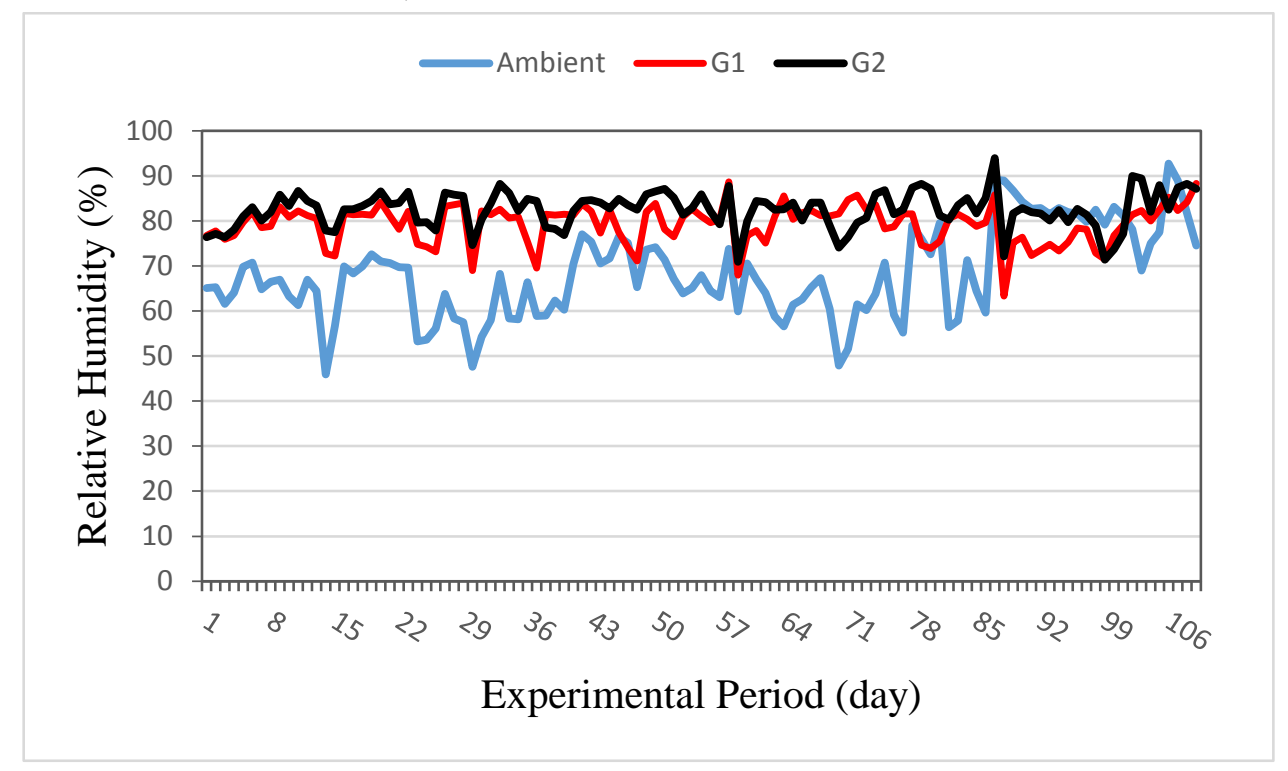

Figure (7): The daily average air relative humidity inside and outside the greenhouses.

Figure (8) shows the hourly average indoor air relative humidity for the two greenhouses (G1 and G2) had compared with the hourly average outdoor air relative humidity. The hourly average indoor air relative humidity was ranged from 57.97 to 88.76 and 60.67 to $93.02 \%$ for G1 and G2, respectively, whereas the outdoor air relative humidity ranged from 45.94 to 82.72 $\%$. The highest values of hourly average indoor air relative humidity were 88.76 and $93.02 \%$ for G1 and G2, respectively, at 7.00 PM, while the lowest values of hourly average indoor air relative humidity were 57.97 and $60.67 \%$ for G1 and G2, respectively, were found at 1.00 PM.

\section{Plant Length:}

Figure (9) shows the effect of different heating systems (G1 and G2) on the cucumber plant length during the experimental period. The results indicate that the plant length increases with increasing plant age. The results indicate that the growth rate for cucumber growth in G1 was higher than that of the plant grown in G2. The length of cucumber plants was 273.60 and 250.17 $\mathrm{cm}$ for G1 and G2, respectively, at the end of experimental period. Increasing plant length for cucumber plants grown in G1 due to the availability of suitable air condition for plant growth period (18.78 to $30.25^{\circ} \mathrm{C}$ temperature). These results agreed with those obtained by Hochmuth (2015) who mentioned that the cucumber is a warm season crop with required growing conditions of 26 to $31^{\circ} \mathrm{C}$.

Regression analysis was carried out to obtain a relationship between the plant length as dependent variable and growth period (1 to 16 week) as independent variables for both heating systems. The best fit for this relationship is presented in the following equations:- 


$$
\begin{array}{lll}
\text { For } G 1 & P \mathrm{~L}_{1}=-118.8+142.72 \ln T & \mathrm{R}^{2}=0.99 \\
\text { For } G 2 & P \mathrm{~L}_{2}=-105.92+129.24 \ln T & \mathrm{R}^{2}=0.96
\end{array}
$$

Where:

$\mathrm{PL}$ is the cucumber plant length, $\mathrm{cm}$

$\mathrm{T}$ is the growth period, week

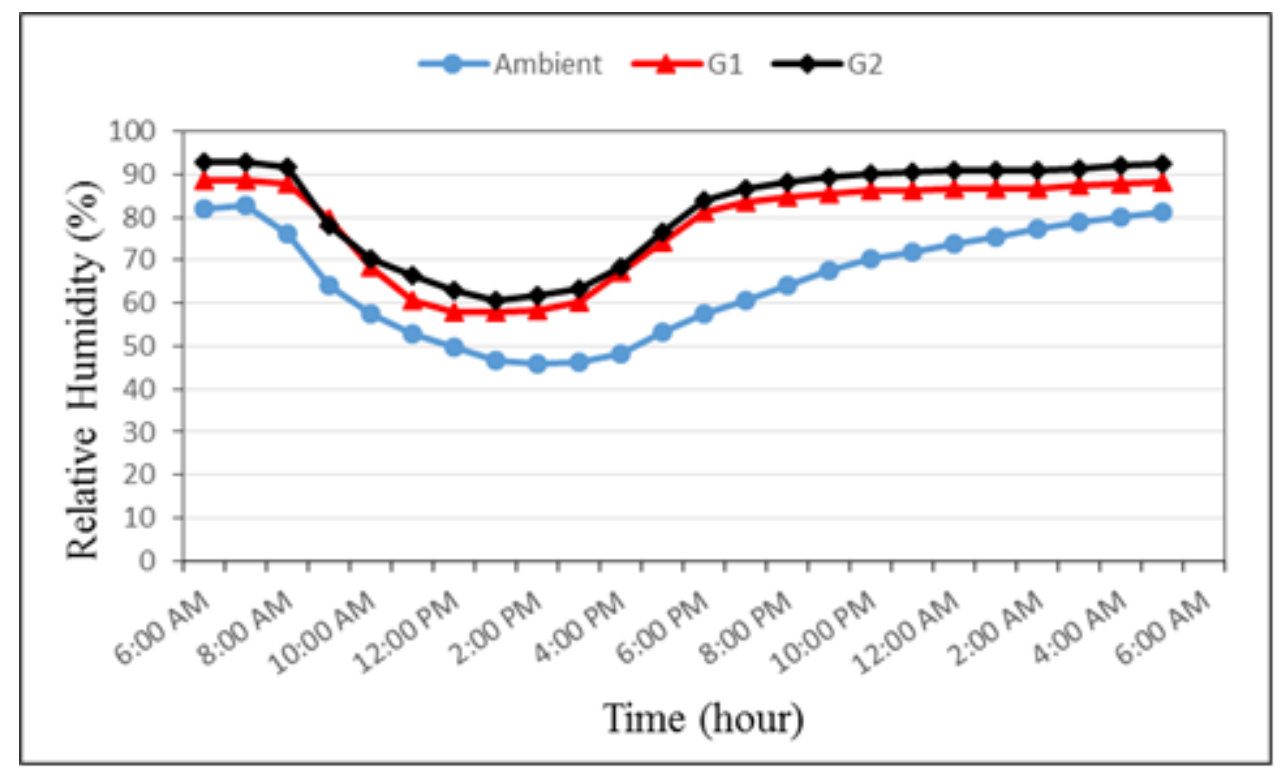

Figure (8): The hourly average Relative humidity inside and outside the greenhouses.

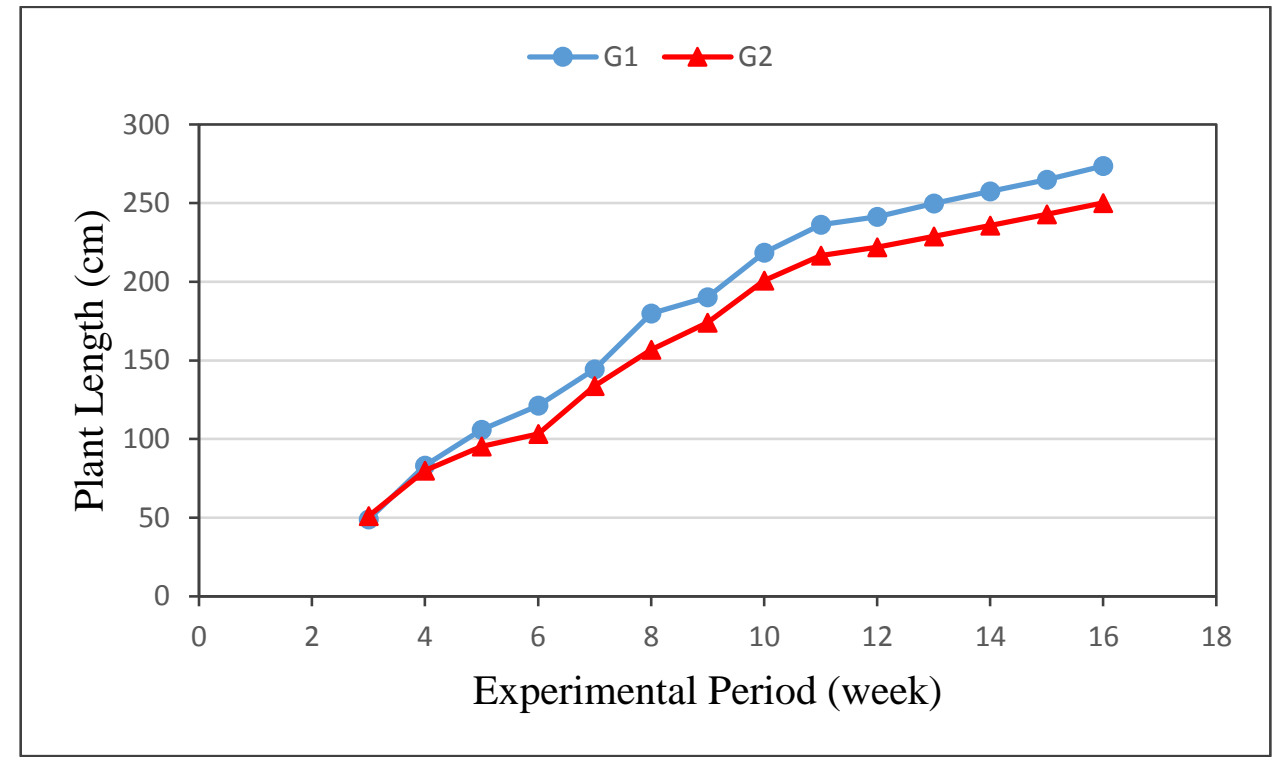

Figure (9): The plant length of cucumber plants grown in G1 and G2 during growth period.

\section{Stem diameter:}

Stem diameter of plant as an indicator of growth was recorded during the growth period for both greenhouse that have traditional heating system (G1) and solar heating system (G2) as shown in figure (10). The results indicate that the stem diameter for cucumber growth in G1 was more than those of the plant growth in G2. It could be seen that the stem diameter for cucumber plants was 7.41 and $7.29 \mathrm{~mm}$ for G1 and G2, respectively, at the end of experimental period. 
Regression analysis was carried out to obtain a relationship between the stem diameter as dependent variable and growth period (1 to 16 week) as independent variables for both of heating system (G1 and G2). The best fit for this relationship is presented in the following equation:-

$$
\begin{array}{lll}
\text { For } G 1 & S D_{1}=-0.044+2.74 \ln T & \mathrm{R}^{2}=0.97 \\
\text { For } G 2 & S D_{2}=0.489+2.45 \ln T & \mathrm{R}^{2}=0.96
\end{array}
$$

Where:

$\mathrm{SD}$ is the Stem diameter, $\mathrm{mm}$

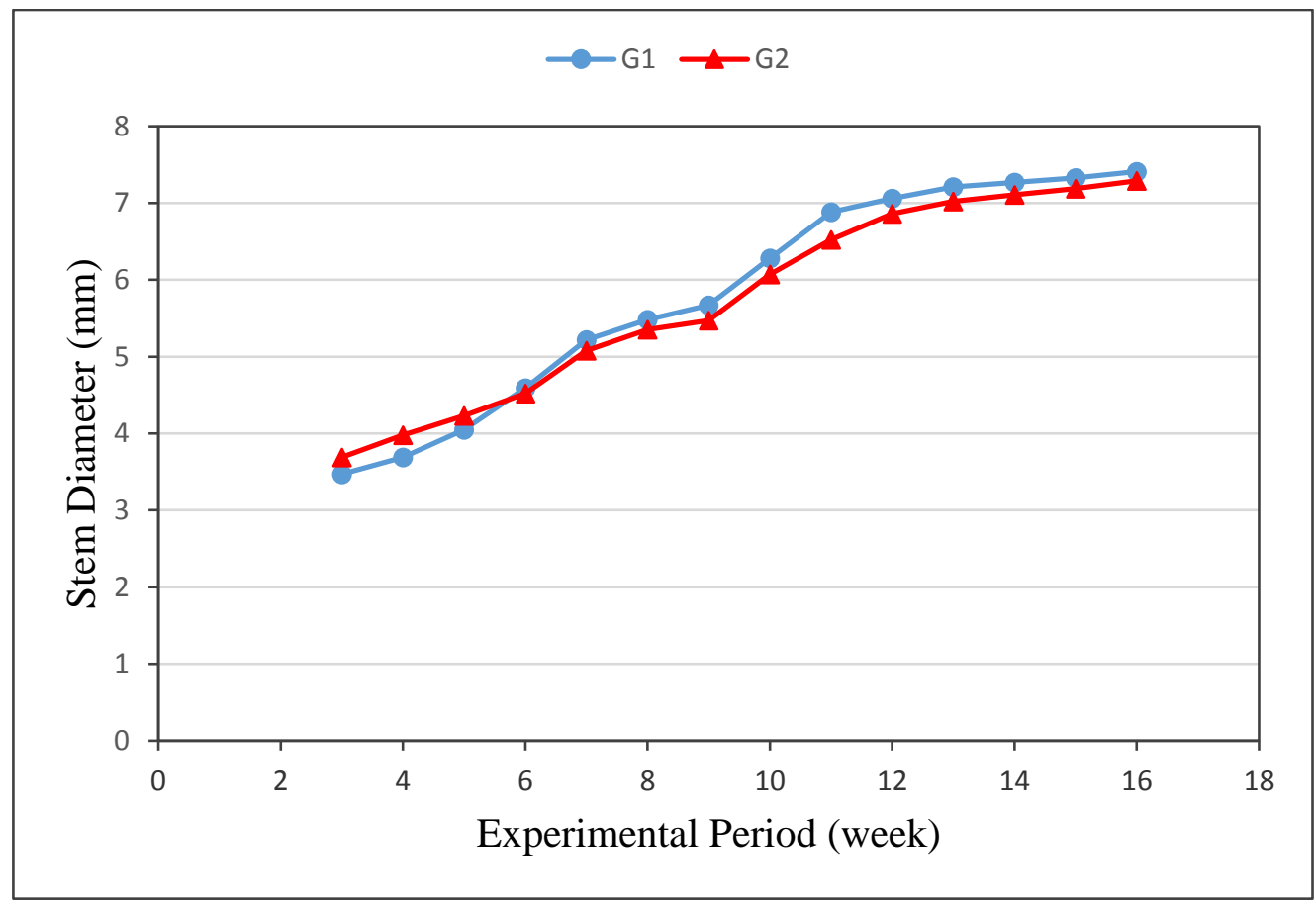

Figure (10): The stem diameter of cucumber plants grown in G1 and G2 during growth period.

\section{Number of leaves:}

Figure (11) shows the number of leaves for cucumber plant during the experimental period. The results indicate that the highest value of number of leaves (50.00) was found of G2, while, the lowest value of number of leaves (14.00) was found of G2. The highest number of leaves recorded during the week 13 both greenhouses (G1 and G2).

Regression analysis was carried out to obtain a relationship between the number of leaves as dependent variable and growth period (1 to 16 week) as independent variables for both of heating system (G1 and G2). The best fit for this relationship is presented in the following equation:-

$$
\begin{array}{lll}
\text { For } G 1 & N L_{1}=-3.37+5.73 T-0.16 T^{2} & \mathrm{R}^{2}=0.97 \\
\text { For } G 2 & N \mathrm{~L}_{2}=-5.06+5.79 T-0.15 T^{2} & \mathrm{R}^{2}=0.96
\end{array}
$$

Where:

$\mathrm{NL}$ is the number of leaves 


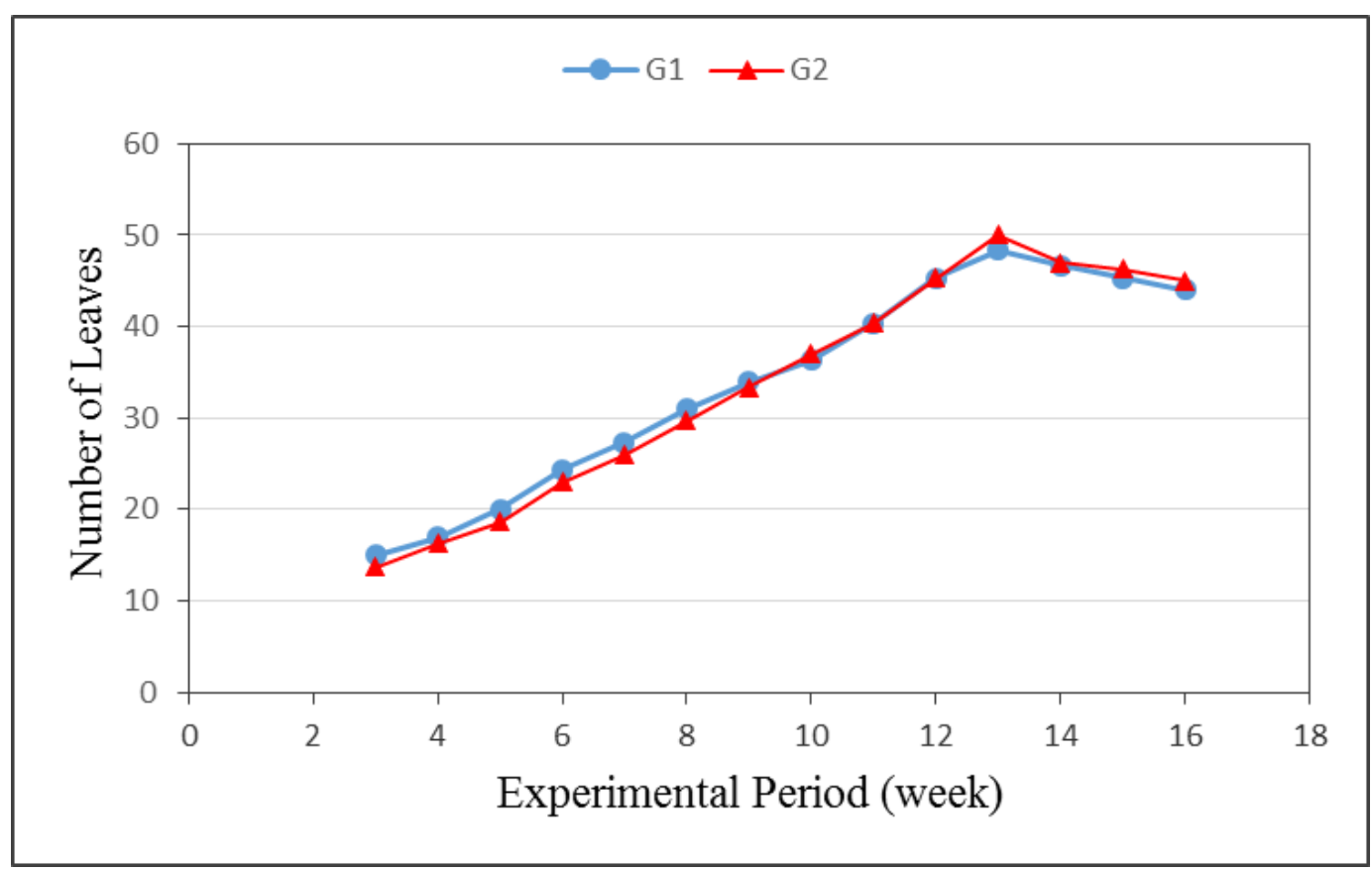

Figure (11): The number of leaves of cucumber plants grown in G1 and G2 during growth period.

\section{Cucumber fruit characteristics and total yield:}

Table (1) shows the effect of different heating systems (traditional heating and solar heating) on the cucumber fruit characteristics and total yield during the experimental period. The results indicate that the fruit lengths were 24.79 and $19.44 \mathrm{~cm}$ for G1 and G2, respectively. The fruit diameters were 3.36 and $3.19 \mathrm{~cm}$ for G1 and G2, respectively. The results also indicate that the fruit weight and number of fruits per plant were 115.07 and $108.73 \mathrm{~g}$ and 19 and 17 for G1 and G2, respectively. The total yield of cucumber was 182.09 and $152.92 \mathrm{~kg}$ for G1 and G2, respectively, at the experimental period.

Table (1): Effect of different heating systems on the cucumber fruit characteristics and total yield.

\begin{tabular}{|l|l|l|l|l|l|}
\hline $\begin{array}{l}\text { Heating } \\
\text { system }\end{array}$ & $\begin{array}{l}\text { Fruit length, } \\
\text { cm }\end{array}$ & $\begin{array}{l}\text { Fruit } \\
\text { diameter, cm }\end{array}$ & $\begin{array}{l}\text { Fruit } \\
\text { weight, g }\end{array}$ & $\begin{array}{l}\text { No. of } \\
\text { fruits/plant }\end{array}$ & $\begin{array}{l}\text { Total yield, } \\
\text { kg }\end{array}$ \\
\hline Traditional & 24.79 & 3.36 & 115.07 & 19 & 182.09 \\
\hline Solar & 19.44 & 3.19 & 108.73 & 17 & 152.92 \\
\hline
\end{tabular}

\section{CONCLUSION}

Cucumber was grown in successively in that heated using two sources of energy, namely electric and solar energies during winter season, where the ambient temperature ranged from 11.00 to $21.66^{\circ} \mathrm{C}$. and relative humidity ranged from 45.93 to $92.73 \%$. Plant growth parameters such as plant length, stem diameter and total leaf area for cucumber growth were higher for electrical heating system compared to using solar heating system. Cucumber yield for greenhouse heating using traditional system was higher by $16.02 \%$ than the cucumber grown 
in greenhouse heated by solar system. Which is not significant compared to the costed system of convential heating.

\section{REFERENCES}

Challa, H., E. Heuvelink and U. Van Meeteren (1995). Crop growth and development. Pages 62-84 in J. C. Bakker, G. P. A. Bot, H. Challa, and N. J. Van de Braak, eds. Greenhouse climate control - an integrated approach. Wageningen Pers, Wageningen, The Netherlands.

FAO (1991). Localized irrigation. Irrigation and Drainage, Paper No. 36: 144P.

Grimstad, S.O. and E. Frimanslund (1993). Effect of different day and night temperature regimes on greenhouse cucumber young plant production, flower bud formation and early yield. Sci. Hortic., 53: 191-204.

Hanan, N., J. Morgan, T. Peterson, J. Reuder, I. Burke and K. Paustion (2003). Carbon, water and land-use in conservation reserve program lands of the short grass prairie. NIGEC-GPRC 2003. Annual Meeting, Lincoln, Nebraska, August 18, 2003.

Khater, E.G., T.H. Ashour, S.A. Ali, M. Saad, J. Todic, J. Hollands and A. Korjenic (2020). Development of a Bio-Solar House Model for Egyptian Conditions. Energies, 13(817): 1-27.

Kittas, C., N. Rigakis, N. Katsoulas and T. Bartzanas (2009). Influence of shading screens on mcroclimate, growth and productivity of tomato. Acta Hort., 807: 235 - 243.

Lazaar, M., S. Bouadila, S. Kooli and A. Farhat (2015). Comparative study of conventional and solar heating systems under tunnel Tunisian greenhouses: thermal performance and economic analysis. Sol Energy, 120: 620-35.

Marcelis, L.F.M. and L.R.B. Hofman-Eijer (1993). Effect of temperature on the growth of individual cucumber fruits. Physiol. Plant. 87: 321-328.

Nelson, P.V. (2006). Greenhouse operation and management. Fourth edition, Prentice-Hall, Inc., New Jersey 07632.

Öztürk, H.H. and A. Başçetinçelik (2003b). Energy and exergy efficiency of a packed-bed heat storage unit for greenhouse heating. hhozturk@cu.edu.tr.

Sethi, V.P. and S.K. Sharma (2008). Survey and evaluation of heating technologies for worldwide agricultural greenhouse applications. Solar Energy, 82, 832-859.

Slack, G. and A. Calvert (1978). Effects of within-night temperature changes on fruit production in early tomatoes. Rep. Glasshouse Crops Res. Inst. 77: 49-51.

Slack, G. and D.W. Hand (1983). The effect of day and night temperature on the growth, development and yield of glasshouse cucumbers. J. Hortic. Sci., 58: 567-573.

Vadiee, A. and V. Martin (2012). Energy management in horticultural applications through the closed greenhouse concept, state of the art. Renewable and Sustainable Energy Reviews, 16(7): 5087-5100. 
Vourdoubas, J. (2004). Comparison of greenhouse heating with geothermal energy, biomass and solar energy. in the conference Geothermal energy applications in agriculture, Athens, Greece.

Zhang, L., P. Xu, J. Mao, X. Tang, Z. Li and J. Shi (2015). A low cost seasonal solar soil heat storage system for greenhouse heating: design and pilot study. Appl. Energy, 156: 213-22. 


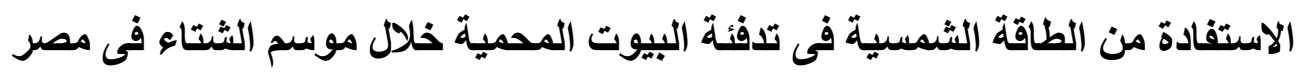

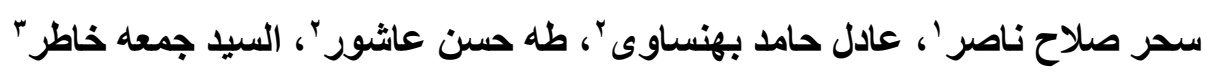

' طالب در اسات عليا - قسم الهندسة الزر اعية ـ كلية الزر اعة بمثتهر - جامعة بنها - مصر.

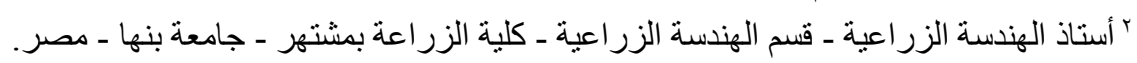

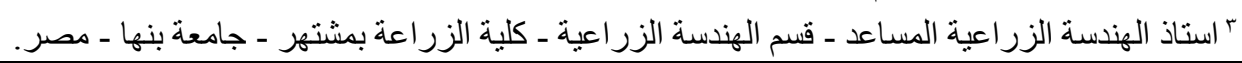

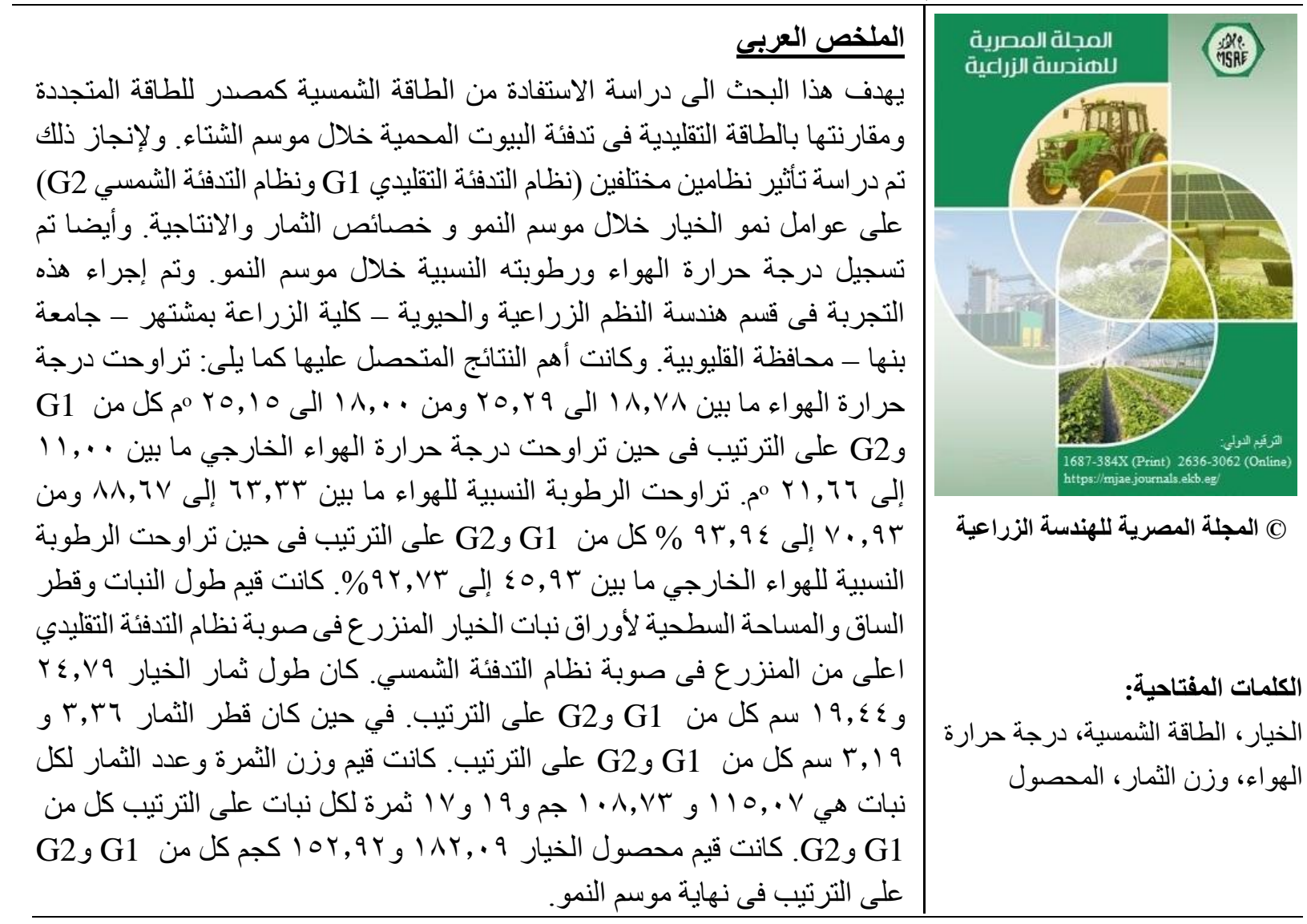

